\title{
The lack of technical conditions as an obstacle to commencing the implementation of penal and security measures in the electronic supervision system
}

\author{
KAMILA MroZEK \\ ORCID: 0000-0001-7973-0281 \\ Department of Executive Penal Law \\ University of Wrocław
}

In the current legal situation, the electronic supervision system may include not only convicts sentenced to imprisonment, but also convicts who have been subjected to criminal measures (prohibition of approaching specific persons and prohibition of entering a mass event) or a security measure in the form of electronic control of the place of stay. The possibility of electronic supervision hinges on several things, among which we can find technical conditions including in particular the number and range of available transmitters and recorders and the organizational possibilities of their operation. The legislator stipulated, however, that in a situation where the technical conditions are not sufficient to simultaneously cover all convicts with mobile supervision for whom such supervision has been imposed, the mobile supervision ordered as a precautionary measure has priority (Art. 43h $\S 2$ of the Executive Penal Code). At this point, it should be mentioned that the penalty of deprivation of liberty in the electronic supervision system is carried out as stationary supervision, while puni- 
tive and security measures as proximity or mobile supervision. The ban on approaching specific people may be performed as proximity or mobile surveillance. This issue is regulated in detail in Art. 431 of the Executive Penal Code. Pursuant to the content of the provision referred to above, if the protected person does not apply to equip him with a portable or stationary recorder within one month of receiving the instruction or declares that he will not use the recorder, the court decides to change the proximity supervision to mobile supervision. The ban on entry to a mass event ruled as a criminal measure and electronic control of the place of stay ruled as a precautionary measure may only be performed as mobile supervision. Chapter VII a of the Executive Penal Code which is devoted entirely to the electronic supervision system introduces the possibility of postponing the execution of the sentence in only one case ${ }^{1}$ and at the same time limits the application of the institution in question only to cases where the control of the offender's behavior using technical means concerns proximity or mobile supervision. The content of article $43 i \S 4$ of the EPC states that it will not be possible to postpone the execution of the sentence in the proceedings concerning the granting of a permit to serve a sentence of imprisonment in the electronic supervision system, i.e. with stationary supervision. ${ }^{2}$

According to the wording of Art. $43 \mathrm{i} \S 1$ and 2 of the EPC the court which executes the penalty with the use of electronic supervision requires the supervising entity to send information whether the technical conditions allow for the immediate commencement of the execution of this penalty, and if not - from what date it will be possible. This solution seems obvious, because it is the supervising entity that has the most authoritative and reliable information in this regard. This issue is somewhat repeated in $\S 1$ sec. 3 of the ordinance of the Minister of Justice on the manner and detailed conditions for the execution of penalties, penal measures

1 According to the wording of Article 43a $\S 2$ point 1 , whenever the provisions of this chapter (VII a) refer to a penalty, these provisions shall also apply to penal and protective measures.

2 By the way, it is worth mentioning that until the entry into force of the Act of March 11, 2016 amending the Act - Executive Penal Code, the legislator allowed for the possibility of postponing, apart from penal measures and a security measure, also the penalty of restriction of liberty, which was then the only sanction specified in Art. 32 of the EPC. 
and security measures in the electronic supervision system, ${ }^{3}$ which regulates the procedure for the execution of penal and precautionary measures in the electronic supervision system. Pursuant to the wording of the above-mentioned provision, after receiving a final judgment or order, or after returning the files to the court of first instance, the court executing the judgment ${ }^{4}$ enters the judgment data into the communication and monitoring system and sends in this system to the supervising entity a request for information whether the technical conditions allow for immediate commencement of enforcement of a criminal measure or a precautionary measure in the electronic supervision system. Thus we can conclude that the supervising entity should inform the court, firstly whether there are any technical conditions allowing for the immediate commencement of the execution of a penal or protective measure, the execution of which is connected with the use of electronic supervision, and secondly - in the event of a negative answer - from what date it will be possible to start implementing the above-mentioned measures. Incomplete information obliges the court to summon the supervising entity to supplement it. It is surprising that the provision does not introduce a deadline for providing information on the existence of technical conditions allowing for the commencement of the execution of a criminal or protective measure. This deadline is set by the court in a letter addressed to the supervising entity, taking into account the immediate requirement referred to in Art. 9 $\S 1$ of the EPC. For if the information obtained from the supervising entity shows that it is not possible to commence the execution of the penalty immediately, the court adjudicates to postpone the execution of this penalty for a specified period. It follows that this is the only condition for the postponement of the measure. It should be noted that the court's decision is obligatory and is made in the form of a decision issued at the

3 Regulation of the Minister of Justice of 10 October 2016 on the manner and detailed conditions for the execution of penalties, penal measures and security measures in the electronic supervision system, Journal of Laws of 2016, item 1698.

4 If the court that issued the judgment in the first instance is not competent to execute the penal procedure or protective measure on the criminal, it shall send a copy of the judgment with the date of its validation to the competent court, in accordance with the norm contained in Art. 43e $\S 3$ of the EPC then, the actions in question are taken by the court competent to perform it. 
meeting without the participation of the parties. The decision on the postponement is issued ex officio, regardless of the parties' activity. Nevertheless, it may happen that the motion for the postponement is submitted by the convicted person (or his defense counsel) or the prosecutor. In such a case, the court should react with a decision granting or not granting the request. The duration of the deferral is predetermined by the legislator and may not, under any circumstances, exceed 1 year (even if its extension is gradual) and is determined by the court. This period is counted from the date of the first decision in this matter. The literature emphasizes that in this decision the court cannot limit itself to stating that it postpones the execution of the measure "until the obstacle ceases" or "for the period of inability to commence the measure". 5 Nevertheless, it should be clearly stated that the postponement of the penalty execution lasts as long as the obstacle is the lack of technical conditions necessary for the immediate commencement of electronic supervision. As it results from $\S 1$ section 5 of the above-mentioned regulation, in the case of postponing the execution of the penalty pursuant to Art. 43 of the EPC the supervising entity informs the court about the change in technical conditions allowing for the commencement of the execution of the sentence in the electronic supervision system immediately, but not later than within 7 days of receiving this information. Moreover, within 21 days before the expiry of the deferral period, the court again sends a request to the communication and monitoring system for information whether the technical conditions allow for immediate commencement of the execution of the sentence. The one-year period is therefore the maximum and non-extendable date of postponing the penalty execution pursuant to Art. $43 \mathrm{i} \S 2$ of the EPC. Although the provisions do not explicitly provide for it, as soon as the situation changes and the technical conditions allow for the immediate commencement of the enforcement of a penal or protective measure, the court should issue an order to cancel the postponement due to the cessation of the reason for which it was granted. This appeal is possible using the structure from Art. $24 \S 1$ of the EPC. As it follows from the wording of the cited provision, if new or previously unknown circumstances relevant to the deci-

5 K. Postulski, Kodeks karny wykonawczy. Komentarz (EPC Commentary), Warszawa 2017, p. 301. 
sion are revealed, the court may at any time amend or revoke the previous decision. It is important, however, that the proposed structure is limited by the time census, because it is unacceptable to amend or revoke the decision to the detriment of the convict after 6 months from the date of the judgment becoming final. The above means that the immediate reaction of the court to the information of the regulating entity about the possibility of commencing the performance of electronic supervision will only take place if the period of one-off postponement does not exceed 6 months. The court should take this circumstance into account when determining the postponement period. It should be emphasized that the date indicated in the information provided by the supervising entity is not binding on the court. Therefore, the legislator should consider the idea of introducing the possibility of revoking the decision to postpone the execution of the sentence directly into Art. 43 of the EPC, without the need to refer to the institution under Art. 24 of the EPC.

It should be remembered that the technical conditions may be subject to dynamic changes, and the supervising entity has the best and most up-to-date knowledge about the availability of technical means and the organizational possibilities of their operation. Therefore, it is reasonable to expect that the emergence of the technical possibility of executing the sentence will be immediately communicated to the court without the need to formulate a separate request. This will undoubtedly affect the level of effectiveness of the enforcement proceedings and shorten its time, allowing in particular for the earlier revocation of the decision to postpone the execution of the penalty and the commencement of electronic supervision. This provision should not, however, infer that the supervising entity is obliged to undertake any field activities, in particular those aimed at ongoing monitoring of the mobile network coverage in the place of the convict's stay. 6

However, if the information obtained from the supervising entity shows that it is still not possible to immediately begin the execution of a penal or precautionary measure, the court shall apply the rules provided for in

6 Justification for the draft ordinance of the Minister of Justice on the manner and detailed conditions for the execution of penalties, penal measures and security measures in the electronic supervision system, p. 8. 
Art. $43 \mathrm{j}$ of the EPC. The lack of technical conditions may be of a longterm nature, exceeding the total period of postponing the execution of penal measures and a security measure, the execution of which is combined with the use of electronic supervision. These rules differ depending on the type of sanction imposed on the convict. According to the wording of Art. $43 \mathrm{j} \S 1$ of the EPC if, after the expiry of the total deferral period referred to in Art. $43 \mathrm{i} \S 2$ of the EPC the information obtained from the supervising entity shows that it is still not possible to commence the execution of a penal measure immediately, the court decides to revoke the control of the prohibition or obligation with the use of the electronic supervision system. Therefore, not the prohibition or obligation itself is repealed, but the control of its implementation by the convicted person in the electronic supervision system. If necessary a penal measure referred to in article 1.39 point $2-2 \mathrm{e}$ of the $\mathrm{PC}$ can be used instead of or in addition to the imposed penal measure. Said replacement measure includes:

- a ban on holding a specific position, performing a specific profession or conducting a specific business activity (Art. 39 point 2),

- prohibition of conducting activities related to the upbringing, treatment, education or care of minors (Art. 39 point 2a),

- a ban on staying in specific environments or places, contacting specific people, approaching specific people or leaving a specific place of stay without the consent of the court (Art. 39 point 2b),

— prohibition from entering a mass event (Art. 39 point 2c),

- prohibition of access to gaming centers and participation in gambling (Art. 39, point 2d),

- order to temporarily vacate the premises jointly occupied with the aggrieved party (Art. 39 point 2e).

It should be emphasized that when determining the need to amend or impose an additional criminal measure, one should take into account the principles and general directives of the sentence referred to in Art. 53 of the Penal Code, taking into account the status as at the date of adjudication in jurisdictional proceedings. An attempt should also be made to assess whether if and to what extent, the impact on the convict, which was to result from this control, was weakened as a result of the repeal of the control of the prohibition or obligation with the use of the electronic super- 
vision system. $^{7}$ The legislator, by granting the court the power to amend the ruled penal measure in the situation referred to in Art. 43j $\S 1$ of the EPC at the same time made a reservation that this change may not cause a greater discomfort for the convicted person than that resulting from the judgment of the court in meriti. The above rules apply in the event of an impediment to the execution of a criminal measure.

This institution looks slightly different if it is not possible to start the enforcement of a precautionary measure. According to the wording of Art. $43 \mathrm{j} \S 2$ of the EPC, if after the lapse of the total deferral period referred to in Art. $43 \mathrm{i} \S 2$ of the EPC the information obtained from the supervising entity shows that it is still not possible to immediately start the execution of the precautionary measure, the court decides on the replacement or revocation of the protective measure. It should be noted that this provision does not specify at any point what the replacement would be. Nevertheless, the decision on the amendment or revocation of the precautionary measure takes place taking into account the principles set out in Art. 93b $\S 3$ of the EPC and procedural requirements relating to adjudication of a change of the protective measure provided for in Art. 199b of the EPC. Therefore, it can only be a change of a precautionary measure in the form of electronic control of the place of stay with a protective measure in the form of treatment or addiction therapy conducted on an outpatient basis. ${ }^{8}$

The decision issued under Art. 43j of the Penal Code may be appealed. The structure of this provision, however, indicates that only the decision to postpone the execution of the sentence may be appealed against. Therefore, an appeal will not be admissible in the event of an order refusing the postponement. In practice, the decision to postpone the execution of a criminal or preventive measure may only be appealed against by the prosecutor. However, it cannot be ruled out that the decision may be appealed against by the convicted person or his defense counsel, for example, alleging that the postponement period is too short. If the intention of the legislator was to be able to appeal against a decision unfavorable

\footnotetext{
7 K. Postulski, op. cit., p. 304.

8 Ibid.
} 
for the convict, he would use the general phrase "in the matter of postponement". This solution should be assessed negatively, as it contradicts the fundamental direction of the amendment introduced to the Executive Penal Code in 2012, which introduced the possibility of appealing against decisions most important to the convict, and the decision on refusing to grant a postponement falls within these limits.

The solutions indicated above apply only when the supervision is inherently related to the implementation of penal or security measures, specified in detail in the Act. Its shape is determined by the content of Art. 43j of the Executive Penal Code.

The issue of the jurisdiction of the court deciding to postpone the commencement of electronic supervision still requires clarification. If, after the expiry of the one-year period of postponement, the information obtained from the supervising entity shows that it is still not possible to immediately commence the execution of a penal or precautionary measure, the court competent to postpone the postponement will be the court in the area of which the convict has his permanent residence, and if the convict does not have such a place - the court in whose district a criminal or protective measure was ordered, carried out in the electronic supervision system. This is due to the fact that this court is competent in matters relating to the exercise of proximity and mobile supervision, and this is the method of supervision used in conjunction with penal or protective measures (Art. 43c $\S 1$ of the EPC).

A certain inconsistency of the legislator in the area regulating the institution of deferment of penalty execution in the electronic supervision system is puzzling. It is difficult to explain the legal privilege of convicts against whom criminal measures or a detention measure are carried out against the background of a much larger group of convicts sentenced to imprisonment, which could be performed in the electronic supervision system. The analysis of the provisions of the Executive Penal Code carried out in this work proves that in the case of those sentenced to imprisonment, the lack of technical conditions referred to in Art. $43 \mathrm{~h} \S 1$ of the CC leads to leaving the application for granting a prisoner a permit to serve a custodial sentence in the electronic supervision system without examination, and consequently the necessity to serve the sentence in solitary confinement. It is true that leaving the application without examination, 
contrary to the refusal to grant a permit to serve a sentence of imprisonment in the electronic supervision system, does not lead to the application of Art. $4311 \mathrm{CC}$, which introduces a 3-month time limit for submitting a new application. Nevertheless, in a situation where the convicted person does not obtain a decision to stay the enforcement of the judgment pursuant to Art. $9 \S 4$ of the CC will have to take into account the necessity to appear in a penitentiary unit in order to serve the sentence of imprisonment, even to a minimum extent. There is nothing to prevent the penitentiary court from issuing — in a situation where the technical conditions allow for the commencement of the execution of the sentence - a decision on granting the prisoner a permit to serve a sentence of imprisonment in the electronic supervision system. This is puzzling, all the more so as the Act of February 20, 2015 amending the Act - Penal Code and some other acts, ${ }^{9}$ due to which electronic supervision was included in the Executive Penal Code, initially provided for the possibility of postponing the penalty of restriction of liberty in the form of the stay of the offender in the place of permanent residence or in another designated place.

\section{Bibliography}

Postulski K., Kodeks karny wykonawczy. Komentarz (EPC Commentary), Warszawa 2017.

\section{Summary}

The issue of postponing the execution of a sentence, or more precisely, a penal measure in the form of a prohibition on approaching certain persons and a ban on entering a mass event performed with the use of an electronic supervision system, as well as a security measure in the form of electronic control of the place of stay, is the subject of this study. As it follows from the content of Art. $43 \mathrm{i} \S 2$ of the EPC in a situation where it is not possible to commence the execution of the sentence immediately due to the lack of technical conditions, the court decides to postpone the sentence. The study explains the definition of the necessary technical conditions and describes the procedure and deadlines for sending information from the supervising entity, referred to in the content of the provision. The court's way of handling a situation and the type of decisions taken in the event that the information obtained from the supervising entity shows

9 Act of 20 February 2015 amending the Penal Code and certain other acts, Journal of Laws of 2015, item 396. 
that it is still not possible to immediately begin the execution of a penal measure or a security measure in the electronic supervision system. The issues related to the jurisdiction of the court in the scope of issuing decisions in the area of the proceedings mentioned in the title were also not omitted.

Keywords: deferment of the execution of the sentence, electronic supervision, imprisonment, mass event. 